\title{
FAMILY PROCESS
}

\section{Identity, Couple and Intergroups Dynamics in Intercultural Families: Implications on Life Satisfaction of Partners}

\begin{tabular}{|r|l|}
\hline Journal: & Family Process \\
\hline Manuscript ID & FP-18-205 \\
\hline Manuscript Type: & Original article \\
\hline Keywords: & $\begin{array}{l}\text { Intermarriage, bicultural couple, life satisfaction, discrimination, ethnic } \\
\text { identification }\end{array}$ \\
\hline \multicolumn{2}{|l}{} \\
\hline
\end{tabular}

SCHOLARONE ${ }^{\text {m }}$

Manuscripts 


\title{
Identity, Couple and Intergroups Dynamics in Intercultural Families: Implications on Life Satisfaction of Partners
}

\begin{abstract}
The current study analyzed how identity, couple and intergroups dynamics are related to life satisfaction among 210 intercultural partners living in Italy. Three levels of analysis were considered: a micro level, taking into account the identity aspect of each partner in terms of self or hetero ethnic identification; a meso level, examining the passion, commitment and intimacy of the couple sphere of the partners; a macro level investigating the discrimination that partners can perceive by the community as an effect of the relationship between dominant and minority groups.

The results show that for both partners, foreign and Italian, the variables that have a predictive value on life satisfaction bring into play the couple and the intergroup dynamics, leaving out the identitary one. Specifically, increased perceived discrimination as a member of a mixed couple leads to a decreased life satisfaction by partners. In turn, we can see that a strong intimacy between partners enhances their life satisfaction. These results introduce a reflection on the role of the differences about the ethnic identity, considered erroneously the main cause of dissatisfaction in the mixed couple. The implications of the study are described and suggestions for future research discussed.
\end{abstract}

Keywords: intermarriage, bicultural couple, life satisfaction, discrimination, ethnic identification

\section{INTERCULTURAL COUPLE RELATIONSHIPS IN ITALY}

The present study analyzed a growing phenomenon in Italy known as intercultural or mixed families.

The mixed (bicultural or intercultural) couple is the union of individuals belonging to different cultural, national or religious contexts (Waldman \& Rubalcava, 2005).

The term 'mixed' (originally, mixité in French) is quite controversial because is a descriptor attached predominantly to individuals rather than to partnerships or households 
and, because it is a dynamic and contextual category based on a perception of diversity in the communities (Novara, Serio \& Lavanco, 2017; Varro, 2003). For this reason we have included 'intermarriage' and 'international' unions to define the relationships between partners from different ethnic backgrounds (Caballero, Edwards \& Smith, 2008), taking into account both the objective components of racial differences and aspects of social construction of ethnic identity (Tajfel, 1981). The mixed family is a significant social institution in which social gaps are visible and these naturalise the differences in daily life (Parisi, 2015).

This new family pattern arises from the political and economic transformations in the world, getting more frequent movements of people from one country to another. In the migration process, mobility among individuals involves a direct continuous contact with members of the host society that gives rise to new acculturation processes, which in turn lead to changes in the original cultural setting of one or both groups (Berry, 2011).

Italy is a new destination of international immigration and has received significant and highly flows of immigrants since the early 1990s (ILFS), a social phenomenon that slowly changes linguistic, ethnic, cultural and religious setting of the city. A component strictly related to this type of mobility is the formation of new intercultural families that are one aspect of the changing cultural landscape of Italy (Riva, 2011).

To certify the relevance of the investigated phenomenon, a reference is made to the official statistics according to which 24.018 marriages have been registered with at least one partner of foreign nationality in 2015 (12.4\% on the total number of marriages in Italy). Among these, the mixed marriages are 74\% (17.692) (where one of the couple is Italian and one is a foreigner); an incidence of nearly $9.1 \%$ on the total number of marriages contracted in Italy (Istat, 2016). In Italy, the mixed couples are distributed respectively in the north $(55.0 \%)$, in the centre $(22.8 \%)$, in the south $(15.3 \%)$ and in the islands $(6.9 \%)$ proportionally to the migratory streams in the different areas of Italy. The 2015 census marks a clear 
prevalence of those cases in which the foreign partner is female and thus, mixed marriages concerned a native Italian man married to a foreign-born woman (77.1\%), mostly originating from poorer countries in Eastern Europe (1 bride on 2) and, to a lesser extent, in Latin America (Istat, 2016). The first 10 nationalities of the brides involved in these marriages were Romania (20.0\%), Ukraine (12.0\%), Russia (6.2\%), Moldova (5.5\%), Albania (5.4\%), Brazil (5.1\%), Poland (4.3\%), Morocco (3.4\%), Peru (2.3\%) and Cuba (2.3\%). Romania (20.6\%), Albania (11.1\%), Ukraine (4.4\%), Moldova (3.3\%) and Poland (2.1\%) were the first five foreign European countries represented in Italy in 2015 (ivi).

To these statistics it is to be added the number of mixed couples living together which are beyond the census and official statistics' control, since the Istat Multiscopus surveys not report the information of the two partners' nationality, which is an unavoidable condition to define the "mixity" of couple. The size of the phenomenon is more realistic when also taking into consideration all those intercultural relationships where the foreign partner has taken Italian nationality. The migrant-native unions, although recently, had a surprising trend, arousing the interest of experts from various disciplines (Adsera \& Ferrer, 2014). A part of them thinks that the growth of intermarriage documented in many developed countries is often regarded as an indicator of immigrants' assimilation into host societies (Alba \& Nee, 2003). Others test the relevance of the status exchange hypothesis to accounting for mixed marriages in Italy according to intermarriage is a gateway to socio-economic integration and stability in the host society (Qian \& Lichter, 2007; Furtado, 2012); others are concerned about the number of divorces (7.160 nel 2015; Istat, 2016) involving these couples (Kalmijn, 2011).

Ethnicity and immigrant status are significant social conditions in the couple formation because of individuals' preferences regarding their own ethnic-related culture such as language, cuisine, religion and traditions and because of the distance between the majority 
and certain minority groups (Potarca \& Mills, 2012). Considering the above-mentioned existence of cultural barriers to exogamy, we argue, also, that the couple affinity is relevant for a proper examination of migrant/native marriages. In this perspective, the relationship between public and private dimensions produces a citizenship expansion on the intimate sphere (Oleksy 2009).

The main objective of this study was to explore a group of variables associated with ethnic identity, intergroup and couple relationships, and to determine how these relate to life satisfaction among partners in intercultural families.

In particular, three different dimensions were examined: identity, intergroup and couple dynamics according to an Ecological Systems Theory (Bronfenbrenner, 1986) to provide a glimpse into the complex interconnections between ethnic, social and romantic realms of experience (Padilla, Hirch, Munoz-Labor, Sember, \& Parker, 2007).

\section{The identity dynamics: ethnic identification}

Regarding the relationship between different ethnic groups in multicultural contexts, Berry (2001) has identified two main currents in recent studies. The first refers to intergroup analysis derived from Social Identity Theory (SIT), whereas the second focuses mainly on the acculturation process.

In current multicultural societies, SIT is the theoretical framework that studies relationships between different ethnic groups (Tajfel \& Turner, 1979; Brown, 2000). According to SIT there are social categories with different status and powers, and the identity of people mainly depends on self-definition in terms of group membership. According to SIT, individuals tend to differentiate between their social ingroup and outgroups, in such a way that their membership constitutes a satisfactory and positive part of ones identity (Hindriks, 
Verkuyten \& Coenders, 2014). Social identity is based on three interconnected processes: categorization, in which the individual builds a membership category related to different factors (sex, age, social status, religion, ethnicity, etc.); identification, through which the individual identifies himself with this group; and finally the social comparison process, through which there is a continual comparison between the ingroup and reference outgroup.

Personal identity is largely determined by belonging to one or more groups and, therefore, influenced by the acculturation process. In fact, according to Castro Solano (2011) and Berry (2003), acculturation can be considered a process of cultural and psychological change that foreigners experience as a result of intercultural contact. The psychological changes experienced by the individuals involve variations in attitudes towards the acculturation process and cultural identity (Phinney, 2003), as well as changes in their social behaviour in relation to the groups in contact. Thus acculturation processes involve complex dynamics through which individuals "negotiate" the ethnic and cultural components of identity via comparisons between their own group and the group represented by the dominant culture (Berry, Phinney, Sam, \& Vedder, 2006).

Berry (1997) argues that there are two fundamental dimensions of acculturation: the maintenance of original cultural identity and the maintenance of relationships with other groups or people from the host society. This model classifies people on the basis of strong or weak affiliation with the host culture and the culture of origin.

Until the 1980s, it was thought that immigrants were free to choose acculturation strategies. From the 1990s onwards, researchers began to investigate how the host society influences the adaptation process among immigrants, finding that the dynamics of acculturation follows a bidirectional model (Berry, 2001), such that perceived discrimination or prejudice on either part may influence which strategies are chosen in the acculturation process (Navas et al., 2004). If the acculturation process is successful, this is known as 
adaptation and may be psychological or cultural. Psychological adaptation is associated with subjective well-being due to cultural contact and is strongly influenced by social support, personality factors and life changes (Ward \& Rana-Deuba, 1999). Sociocultural adaptation refers to the successful resolution of practical problems arising from interaction with members of the dominant culture (Castro Solano, 2011) and is influenced by interaction with the host culture, proficiency in using the host language, and discrimination (Ward, 2004).

Numerous studies have shown that psychological or sociocultural adjustment is linked to the type of group identification that individuals develop. Thus, identification with one's culture of origin is associated with a lower incidence of psychological distress (Bratter \& Eschbachb, 2006) and subjective well-being (Kenyon \& Carter, 2011), lower levels of depression (Ward \& Rana-Deuba, 1999), higher self-esteem (Espinosa, Freire \& Ferrándiz, 2016), higher rates of well-being (Haslam, Jetten, Postmes, \& Haslam, 2009) and increases life satisfaction (Arpino \& de Valk, 2018). However, strong outgroup identification has been linked to lower levels of sociocultural difficulties (Ward \& Kennedy, 2001).

Finally, based on Berry's acculturation model (1997), foreigners who adopt the strategy of maintaining both cultures (integration) receive the greatest functional benefit. In particular, it has been shown that the integration strategy is associated with lower levels of depression (Ward \& Rana-Deuba, 1999), greater life satisfaction (Castro Solano, 2011), and greater psychological and sociocultural adjustment (Berry et al., 2006).

\section{Intergroups dynamics: the perceived discrimination}

Common assumptions about mixed relationships still tend to over-privilege stereotypical conceptualisations (Caballero et al., 2008). 
The social comparison process of the SIT shows not only a positive valuation of ingroup but also a devaluations of other groups. This internal social comparison process drives the intergroup conflict, even in the absence of explicit rivalry or competition between groups (Padilla \& Perez, 2003). We consider that intercultural families can be considered as a new outgroup for the majority and minority group. Consequently, this social categorization process reflects on perceptions, attitudes and behaviour toward exogamous relationship (Rodriguez, 2004).

In countries where the multicultural phenomenon is more common, researchers have focused on the intergroup relationships in ethnic minority contexts (Esses, Dovidio, Jackson \& Armstrong, 2001). These studies highlight the importance of the comparison between the dominant and minority groups. These relationships evolve according to the balance of power in function to the national group membership. In this way, a common representation is formalized as the strongest versus the weakest, the majority versus the minority and the dominant versus the dominated. For these reasons, this research takes into account the relationship between groups (Panari, Mancini \& Fruggeri, 2010): in fact, the foreign partner has to interact with the indigenous partner's group, which is the dominant group/culture. The difference between the members of the mixed couples (cultural, religious, racial, ethnic, etc) assumes importance if the cultural difference between the respective groups is perceived as relevant to the community context in which the couple lives. Hence, it is necessary to understand the process of cultural construction of similarities and differences between groups that, according to a hierarchical group model, which implicitly shared, establishes the acceptance levels between groups (Bertolani, 2015). In function to the social contact established with those groups that boast of greater prestige (Allport, 1935), a discriminatory attitude takes shape against the foreign partner if the foreign partner is associated with minority group. This level of analyses is connected to the social-constructivist model 
(Gergen, 2009), where it is assumed that social construction of difference and its consequential discriminative processes can obstruct the development of the foreign partner's sense of belonging.

As it has been demonstrated, the perception of these feelings has a negative impact on the wellbeing of foreigners (Killian, 2012). For example, the perceived discrimination due to cultural differences or feelings of maladjustment are associated with low levels of self-esteem and life satisfaction (Vedder, Van de Vijver, \& Liebkind, 2006).

According to Schmitt \& Branscombe (2002), prejudices have a negative effect on wellbeing, increase hostility towards the dominant group and encourage minority group identification. Furthermore, group identification would attenuate the negative effects of perceived discrimination on psychological well-being. Research on intercultural couples has shown that not only are they considered incompatible on a social level (Tognetti Bordogna, 1996), but they experience hostility toward your union from family and friends when they announce their engagement (Carol, 2013; Mancini, Panari, \& Fruggeri, 2013).

Some studies have shown that prejudices negatively influence the well-being of mixed couples, whereas others have suggested that stereotypes, together with camouflage and miscommunication, are the main process that underlie discrimination against intercultural couples (Molina, Burnett, \& Estrada, 2004). Furthermore, in the case of interreligious and interracial unions, if the extended family members or the closest members of society consider the interreligious or interracial union a threat, then integration becomes yet more difficult for these families (Hombrados \& Moscato, 2009). A recent study conducted in Spain found that the perceived discrimination due to being a member of this type of family is one of the factors that has the greatest negative impact on life satisfaction (Moscato, 2012). Most of these studies have focused on the problems that arise from being members of interreligious families (Romano, 2008). 


\section{Couple dynamics: conjugal wellbeing}

People from different country, with different cultural backgrounds and traditions unavoidably come together around the world and fall in love. That seems like obvious, but intercultural relationships are still a quite controversial issue. In fact, as previously mentioned, the family, friends and the community often perceive mixed union negatively. Moreover, cross-border marriages are thought to be less satisfying and more prone to failure (Gurung \& Duong, 1999) and they are sometimes judged as a choice of convenience (Eggebø, 2013).

In Italy, studies converge into a structural approach abandoning the seventies pathological viewpoint according to which exogamy was an aggressive choice towards own ethnic origins (Novara \& Lavanco, 2014). This non-prejudicial viewpoint, explains the increase of mixed unions with a greater social contact and openness towards the migrant population. Also other studies (Leslie \& Letiecq, 2004) examined ethnic identity, social support, and experience of discrimination in predicting intermarriage quality, considering the mixed couple in a macrosocial sight. However, this focus may lead to underestimate the point of view within the couple if aspects of the intimate relationship, such as falling in love and passion typical in a conjugal choice, are not taken into consideration (Leslie \& Young, 2015).

Currently, the studies that have compared mixed and mono-cultural couples noticed the absence of differences in relationship quality, conflict patterns, relationship efficacy, coping style, and attachment, casting doubt on the belief that interracial relationships are burdened with more problems than intra-racial relationships (Troy et al., 2006). These evidences can be explained by the model of Yodanis \& Lauer (2017) according which, in interethnic relationships, the assimilation or a breakdown of ethnic group boundaries must not 
necessarily take place; ethnic differences can remain central as people meet, fall in love, and marry across these same (ivi).

Therefore, intercultural like mono-cultural couples undergo challenges such as mutual accommodation and adjustment for possible different habits, moods and life styles (Gaines, Clark \& Afful, 2015). They also both share the basic needs for affection, support, trust, and respect from one another essential in maintaining a satisfying conjugal relationship (Skowroński et al., 2014).

Based on the above, intercultural marriages might face a particular set of couple dynamics - as compared to mono-cultural couples - due to their cultural differences but love that characterizes romantic relationships remains central across social, cultural, and national boundaries (Wieling, 2003). For this reason, Sternberg's triangular theory of love (1997) that is sufficiently general and may be applicable across cultures - was taken in exam. Sternberg's model proposes three components of the falling in love among partners: intimacy, passion, and commitment. Intimacy includes the close bonds with the loved one: mutual understanding, emotional support, intimate communication, and approach in the relationship based on the sharing. The second component, passion, refers to romance, physical attraction, desire, belonging, and sexual satisfaction in a love relationship. The last component refers to a short-term decision to love the other person establishing a long-term commitment to maintain the relation.

In this study, we take into account the potential difficulty of the couples to cope with differences in the intimate family relationship using the triangular theory of love as couple dynamic model (Gao, 2001) and indicator of conjugal wellbeing (Torqabeh, Firouz \& Haqshenas, 2006). 


\section{RESEARCH AIM AND HYPOTHESIS}

The complexity of the phenomenon of bicultural couples is reflected in involved demographic, politic and psychological factors. Only recently, in Italy studies go beyond individual motivations to deal with intergroup, family, symbolic aspects such as emerges from Fruggeri's multidimensional model (2007). Actually there are not empirical proofs to describe mutual interactions and implications of an analysis level on another; for this reason, the general aim of the research was to investigate the three levels above mentionated cultural identification, perceived discrimination and conjugal wellbeing - considering them fundamental variables for life satisfaction of partners in binational couples.

In particular, the research had the following specific objectives:

- Ob. 1: verifying the presence of significant differences between two sub-samples foreign and autochthonous partners - on all considered levels; and also the differences within sub-samples in relation to sex, emigration motives, interreligious factors. In line with this objective we derive the hypothesis 1: there will be no significant differences between foreign and authoctonous partner regarding ethnic identification, perceived discrimination, conjugal wellbeing and life satisfaction.

- Ob. 2: examining the relationships between the three levels above described; in line with this objective we derive the following hypotheses:

hypothesis 2 : we expect that the ethnic identification with own group of origin does not correlate with the life satisfaction of both partners;

hypothesis 3 : we expect that the perceived discrimination is negatively correlated both with life satisfaction and conjugal weellbeing, for foreign and Italian partners.

- Ob. 3: analyzing whether the ethnic identification, perceived discrimination and conjugal satisfaction are predictive of the life satisfaction for foreign and Italian 
partners. In line with this objective we derive the hypothesis 4: we suppose that the variables concerning the ethnic identification are not good predictors of life satisfaction for both the partners, while are so perceived discrimination and conjugal wellbeing.

\section{METHOD}

\section{Participants and Procedure}

Taking into account the difficulties involved in obtaining a stratified sample due to problems in recruiting this group of individuals, we decided to use the snowball sampling method. The participants were recruited through advertising in Italy. Those recruited were then asked to invite any other member of mixed couples they knew to participate in the study. The advert for participants in the study was published online on sites frequented by mixed families. It was also posted in official buildings, such as the registration office, foreign associations, hospitals, etc.

According to APA Ethical Principles, all were asked to sign informed consent letter.

The sample included 210 partners of 105 mixed couples residing in Italy. As shown in Table 1, the sample is mainly composed of foreign partners with European origin (36.9\%), from EU member countries prior to 2004 or from new European member countries, (specifically Poland and Romania), which joined after 2004; Africa (26.2\%), Sud America (14.6\%), other European countries and USA and Australia (12.6\%), Magreb and Middle Eastern (9.7\%).

The proportion of gender in the sample reflects in the population the prevalence of mixed couples formed by a woman foreign partner and an indigenous partner (Guetto \& Azzolini, 
2015 ) with the $7.9 \%$ of total celebrated marriages in 2012 consisting of Italian man and foreign woman).

Table 1 - Demographic Variables

In the sample we included married couples $(73.3 \%)$ or living together partners $(26.7 \%)$ and in $51.2 \%$ of cases with children.

With regard to age and education, the sample confirms that members of minority groups with a high educational profile marry more frequently exogenously, than those with a lower degree of education. Infact, according to Furtado and Theodoropoulos (2011), highly educated immigrants have wider social contacts and are more likely to accept the cultural norms prevailing in the host country. They therefore are more interested in similarities in education than similarities in ethnicity. In our case, the hypothetical "cultural disadvantage" of the foreign partner is compensated by the variables age and title of study: the mean age of autochthonous partners is slightly higher $(\mu=38.5, s d=10.9)$, and $29.8 \%$ have a degree, while foreign partners are younger $(\mu=36.6, s d=10.2)$ and $34.7 \%$ of them own degree. These data confirmed other similar demographic elaborations based on the Italian Labour Force Survey (ILFS, 2005-2012): Italian men are more likely to be married to a non-Western woman than to an Italian one where he is old and low-educated and she is high-educated (Balistreri et al., 2017).

The foreign partners had lived in Italy for an average of 12.8 years $(s d=9.6)$. The majority of participants claimed they were employed. The reasons for migration to Italy, confirming other studies (Tognetti Bordogna, 2005), were for better economic circumstances (43.4\%) and/or familial and emotional reasons, for example, family groups (35\%).

Italian partners are for the most part (90.7\%) of Christian religion, so in some cases there is a situation of interreligious couples. Regarding the level of religiosity $47.1 \%$ of Italian 
partners declare to be "nothing" and "little" religious, and $52.9 \%$ to be "fair" and "very", while foreign partners are respectively $36.5 \%$ and $63.4 \%$.

Regarding the way autochthonous have met the foreign partner, the highest percentages are recorded on "Italian friends" $(24.8 \%)$, "for study or work" $(21.0 \%)$, "on vacation in foreign countries" (15.2\%), "through friends in her/his country" (11.4\%).

\section{MEASURES}

\section{Indipendent variables}

Ethnic Identification.

The group identification scale (Brown, Condor, Mathews, Wade, \& Williams, 1986) was used to measure Ingroup Identification (below Ingroup Id). This scale consists of 10 items, 5 positive and 5 negative, using a 5 -point Likert scoring system $(1=$ never, $5=$ very often $)$. This scale was originally used in organizational contexts and measures three dimensions of group identity (awareness, evaluation and affect). It is considered one of the most effective scales for measuring identification with ethnic/cultural groups, as it provides direct correlation between the attachment group and the ethnic/cultural group (Duckitt \& Parra, 2004). Ingroup identification was used as an overall measure in this study (foreigners partners $\alpha=.77$; autochthonous partners $\alpha=.87$ ).

To measure the identification with the partner's ethnic group or Outgroup Identification (below Outgroup Id) were used the same items taken from the group identification scale. The scale maintains the item structure of the original instrument, but refers to the partner's cultural group (i.e. "I identify myself with my partner's culture" or "I criticize my partner's culture"). 


\section{Discrimination perceived.}

The measure of Discrimination perceived by the mixed couple (below Couple Discrimination) consisting of 8 items using a 4-point Likert-type scoring system (foreigners $\alpha$ $=.69$; autochthons $\alpha=.79$ ). By way of example, the items used to measure discrimination towards couples in three contexts were as follows. For the social context: (1) As a result of marrying/cohabiting with a foreigner man/woman I feel badly treated here in Italy; (2) On the whole, Italian society views intercultural families as being different; (3) Mixed families are viewed favourably in Italy. For the family context: (4) Members of my family of origin are sometimes critical of my partner's culture; (5) Members of my partner's family are sometimes critical of my culture; (6) Our families of origin sometimes interfere in our family life (running the household, bringing up children, religion, food, etc.). For the friendship context: (7) My friends have a positive view of my partner's culture; (8) My partner's friends have a positive view of my culture.

To measure the Discrimination perceived exclusively by the foreign partner (below Foreigner Discrimination) was used a scale that consists of 4 items using a 5-point Likerttype scoring system $(1=$ total disagreement; $5=$ total agreement $)$. It was constructed ad hoc for foreign partners. On this scale $(\alpha=.80)$, discrimination is interpreted as direct experience, that is, the degree of rejection experienced by the foreign partner in the host society. The scale has the following items: (1) I receive few services due to being a foreigner in Italy; (2) I sometimes feel excluded or ignored in Italy; (3) I sometimes feel like I am treated with little respect; (4) It is difficult to find work at my level of education in Italy.

\section{Conjugal Wellbeing.}

The measure of this variable was the Triangular Love Scale of Sternberg (1997) (foreigners $\alpha=.86$; autochthons $\alpha=.90$ ). According to Torqabeh et al. (2006), Sternberg's 
love scale components (intimacy, passion, commitment) were significantly related to scores of relationship satisfaction. In the original version, the scale consists of 45 items (15 item for each dimension) while we used the small version of Cassepp-Borges and Teodoro (2007) with 18 items (6 for each dimension) using a 5-point Likert-type scoring system $(1=$ total disagreement; 5 = total agreement).

\section{Dependent variable}

\section{Satisfaction with Life.}

To measure the Satisfaction with Life (below $S w L$ ), the unidimensional scale constructed by Diener, Emmons, Larsen, and Griffin (1985) was used. The scale is composed of 5 items using a 7 -point Likert-type scoring system $(1=$ total disagreement $7=$ total agreement $)$ and shows the subjective evaluation of the individual's own sense of satisfaction with life. The scale has been frequently used in research related to subjective wellbeing in communities (foreigners, $\alpha=.91$; autochthons $\alpha=.92$ ).

\section{Data analysis}

The analysis was carried out with the statistical package SPSS 15.0. We conducted the analysis of variance (ANOVA between and within) to compare the mean scores obtained by the two groups of foreigners and Italian partners. Pearson's Coefficient was used to analyze the association between variables. Stepwise multiple regression analysis was chosen to evaluate the effects of the variables on satisfaction with life. Specificaly, for the test of each effect, we used the sequential procedure to mantain the study-wide Type I error rate at $p=$ .05 . 


\section{RESULTS}

\section{Differences between Italian and foreign partners}

The differences found between the two groups of Italian and foreign partners on three levels of analysis are shown in the Table 2. First observation concerns the scores of Ingroup Id e Outgroup Id which appear high for both groups. Operating an ANOVA it was found a significant difference on foreigners who show a higher level of Ingroup Id than Italian partners $(F=2.941, p=.05)$. Instead, there are not significant differences for Outgroup Id; it means the double ethnic identification with own group amd host group is a real possibility for foreign partners.

Table 2 - Comparison between sub-samples (Anova)

No differences are found between Italian and foreign partners inside the other dimensions analyzed. Specially, it is low for both the perception to be discriminated as a mixed couple (foreigners range $=2.09$, Italians range $=2.01$ ). About Conjugal Wellbeing, the situation is equivalent in both groups, Italian and foreigners, obtaining medium-high level (foreigners range $=4.42$, Italians range $=4.44$ )

\section{Differences within foreign partners groups}

The foreign females have a major Outgroup Id than males $(F=7.166, p=.009)$, which while consider mixed couples as more discriminated than females $(F=5.094, p=.026)$, (Table 3). These results are confirmed by other recent researches that see immigrant femals as more inclined to assume integration strategies (Berry, 2003) and to adopt easily values of 
the new community, nevertheless maintaining the original culture. This strategy requests a specific motivation by women to adopt the basic values of receptive community, in order to find new services for their needs (education, health, work, etc.).

Table 3 - Comparison within sub-sample (foreign partner) (Anova)

As regards to the type of emigration, Couple Discrmination and Foreigner Discrimination are more perceived by who considers his/her own migration as forced (political refugees and asylum seekers) compared to who cosiders it as volunteer (linked to economic factors or for educational reasons or other) (respectively, $F=17.825, p=.001 ; F=5.901, p=.017$ ). Individuals with a volunteer migratory project record also major values of Conjugal Wellbeing, especially Intimacy $(F=4.689, p=.033)$ and Passion $(F=5.836, p=.018)$;

About sense of religiosity, this variable is confirmed as a strong ethnic element (Heller \& Wood, 2000) so that who claims to be "highly" religious shows higher Ingroup Id compared to who is "enough", "little" or "not religious at all" $(F=5.145, p=.002)$. Furthermore, the context is perceived more discriminant towards mixed couples from the muslim partner compared to other with a different religion $(F=3.185, p=.017)$.

Undeniable, the mass media prejudice towards some ethnic minorities and the role of fundamentalism as watershed between acceptability and refusal of some religious practices. To conferm this, in the interreligious couple we find a stronger perceived discrimination both as partner of mixed couple $(F=7.049, p=.009)$ and foreigner $(F=4.859, p=.030)$; in these unions, the couple dynamic is reflected in a minor Intimacy with the partner $(F=3.185, p=$ .017) (Table 3). 


\section{Differences within Italian partners groups}

In Italian partners groups the differences are statistically significant for variables shown in Table 4.

About gender, Italian females who chose a foreign partner perceive more discrimination as partners of a mixed couple $(F=6.127, p=.015)$ compared to Italian males; on the other side, in the sub-scale Passion, women have high medium score $(F=9.788, p=.002)$. The result seems to confirm a disapproval in the social context to recognize to the woman the "power" to choose her partner out of her own ethnic enviroment.

Among Italians, who works has high scores for Ingroup Id $(F=6.941, p=.010)-$ maybe because job is an integration way in any life contexts - but also for Commitment inside the couple $(F=4.949, p=.028)$.

Table 4 - Comparison within sub-sample (Italian partners) (Anova)

Finally, the presence in the couple of a difference in religion for Italian partners affects the perception of discrimination $(F=13.575, p=.001)$ while there are no differences on the couple's dynamic how happens for the foreign partner.

\section{Correlations}

Correlation between Ingroup Id and Outgroup Id in both groups is around zero, disconnecting the identification to its own ethnic group from the concept to belong or not to new context (Table 5). Maintaining an anchorage to one's own culture of origin is, and should be, a private choice of individuals that does not affect the openness to new memberships. 
The ethnic identification is affected by discriminatory process. In fact, for foreign partners, Outgroup Identification is associated negatively with Couple Discrimination $(r=-.35, p<$ $.001)$ and Foreigner Discrimination $(r=-.26, p<.001)$.

Table 5 - Correlations among all dimensions for Autochthonous and Foreigners partners

The identification with outgroup has a significant importance in modulating the couple dynamic, for both partners' groups; how it shows in table 5, for foreigner partners, the Outgroup Id links positively with all dimensions of the Conjugal Wellbeing. Only for foreigner partners, the Outgroup Id affects the $S w L(r=.32, p<.001)$.

Moreover, it is interesting to notice that the discriminant dynamic affects the couple dynamic: we find that all the dimensions of Conjugal Wellbeing are negatively relate with the pervceived discrimination as mixed couple, specially for non-authocthonous partner; furthermore, in the latter, more is the Foreigner Discrimination less is the Intimacy among partners $(r=-.28, p<.001)$. How we expected, the two measures of discrimination are related each other $(r=.46, p<.001)$.

Finally, all dimensions of Conjugal Wellbeing are positevely related to $S w L$, for both subsamples.

\section{Predictive Model}

In order to test which among levels - indentity, discriminant, couplet - may have a predictive value on $S w L$, it was done an analysis of linear regression (Stepwise Method). In the model, a single dependent variable was inserted for the three involved levels, with $S w L$ as dependent variable and Outgroup Id, Couple Discrimination and Passion, as predictive 
variables. Among the Conjugal Wellbeing dimensions, it was chosen Passion because is linked mainly with $S w L$ for the foreign partners (see Tab. 5).

Following, you find the output of two models which were found statically significants for Italian and foreign partners (Tab. 6).

Table 6 - Lineal regression in both sub-groups of native and foreign partners

Specifically, for the native partners, the variables that predict $S w L(F=2.101)$ are Passion $(\beta=.46 ; p<.001)$ and Couple Discrimination $(\beta=-.30 ; p<.001)$. The model explains the $30.6 \%$ of variance (Adj $\left.\mathrm{R}^{2}=.306\right)$. Also for foreign partners, the varibles able to predict the $S w L(F=$ $2.100)$ are Passion $(\beta=.56 ; \mathrm{p}<.001)$ and Couple Discrimination $(\beta=-.19 ; \mathrm{p}<.01)$. The model explains the $41.1 \%$ of variance $\left(\operatorname{Adj} \mathrm{R}^{2}=.411\right)$. However, these results show that Outgroup Id does not predict $S w L$, which instead is predicted by Passion and Couple Discrimination.

The multicollinearity has been examined with Tolerance and the Variance Inflation Factor (VIF), two collinearity diagnostic tests. The Tolerance is good and the VIF (value lies between $1-10=$ no multicollinearity), measuring the impact of collinearity among the independent variables, has been satisfied.

\section{DISCUSSIONS AND CONCLUSIONS}

Numerous studies tried to explain the birth of mixed couple, but continues to be scarce the knowledge of identity processes, intergroup and intimacy dynamics of these couples, once formed. This paper gives a contribution to this literature.

Intermarriage has been considered by some author an example of social integration (Song, 2009), but others states that it is not true that who get marry with an native has already 
obtained a 'structural' integration, a residential, cultural or economic (Rodriguez-Garcia, 2015). Moreover, generally migrants have a low socio-economic profile and scarce possibilities in 'social mobility', whereas mixed marriages may be seen as a tool of socioeconomic integration (Choi at al., 2012) instead of have been considered as effects of better synergy among groups (Azzolini, \& Guetto, 2017).

The rethoric on 'arranged marriages' has casted suspicion on this population. Mixed marriages are often prone to unusual controls by public opinion in order to certificate the authenticity of tie through comparisons about aesthetic, moral, age and socio-economic status among spouses (Lehmiller, \& Agnew, 2006). That forced mixed couples to a diffuse system of 'surveillance' from relatives, society and State. Inevitably, in these conditions love relation is not only a private fact and flags identity and social issues (Parisi, 2015).

Therefore, the paper examines if the differences socially built in the public sphere - as cultural identification and perceived discrimination - are related with couple relationship and if its together may affect the private satisfaction with life.

As we expected in the hypothesis 1 , there are not significant differences between foreign and autochthonous partners regarding perceived discrimination, conjugal wellbeing and life satisfaction; differently, it results that the foreigners have a ingroup identification value slightly higher than their partners. That evidence together with high levels of outgroup identification could be the sign that each partner can both maintain an anchorage to one's own ethnic identity and opening to other's culture. Furthermore, the identification with outgroup seems to help the minority partner to feel 'belonging' to the dominant culture. As Berry (1997) claims the integration strategy, where individuals maintain the original cultural identity and at the same time become participants of the new host culture, may guarantee a better process of adaptation. This double identity would seem adapt and functional when it 
avoids a pure assimilating situation, where one of the two cultures prevails over the other and permits the coexistence of each uniqueness (Helms et al., 2014).

About the hypothesis 2, the results confirm that the identification with own group of origin does not correlate with the life satisfaction for both groups' partners, while the outgroup identification is related with all the dimensions of conjugal wellbeing and, only for foreigners, also with the life satisfaction. That can be explained by the process of similarities' maximization according to the SIT (Pagliaro et al. 2010), in which foreigners try to emphasize what is common between the self and the majority group to improve their life conditions. In the couple dimension, it is as if the partners redefine the boundaries of their differences focusing on perceived similarities with partner's group giving birth to a transnational identity (Faist, Fauser, \& Reisenauer, 2013): a mixed identity of couple. In fact also for the italian partners identify with the native group of the foreign partner enhances the conjugal wellbeing: how stated above, the exogamic choice could derive from the attractive power of the differences between partners thus contributing to the falling in love and the couple’s affinity (Yodanis \& Lauer, 2017).

Going over we can add that the identification with outgroup seems to have weight positively on partners' life and couple's satisfaction, provided that they do not perceive to be discriminated. In fact, how formulated in the hypothesis 3, we found that the perceived discrimination is negatively correlated both with life satisfaction and conjugal wellbeing, for foreign and Italian partners. We found also that the discrimination as foreigner is inversely related to the identification with the Italian partner's group but not to the identification with own native group. This result is very interesting because it emerges the prescriptive role that can have the host culture (Pagliaro et al., 2010). According to SIT, discriminating behaviours underline 'cultural distance' among individuals. This is the reason why, in comparison within 
sub-sample (Tab. 3), foreign partners in inter-religious couple feel discriminated, especially the Muslim (Joseph, Yun, \& Teya, 2017; Riva, 2011; Heller \& Wood, 2000).

Thus, the macro level has a key role in to promote a general wellbeing but no affects the issue referring to ingroup identification.

For these reasons we analyzed to what extent the ethnic identification, perceived discrimination and conjugal satisfaction are predictive of the life satisfaction for foreign and Italian partners.

The predictive model - as described in the hypothesis 4 - confirms that the perceived discrimination and conjugal wellbeing are good predictors of the life satisfaction, for both partners' groups. Also in this case, the cultural identitfications' level is not decisive.

Overall, the results reported here show that the identity dimension can be flexible and that sense of membership in migratory contexts can be built safeguarding also the couple relationship. Instead, essential condition for quality of life perception, as for monogamous couples also for the partners of mixed union, is the conjugal wellbeing. On the other hand, (social and legal) 'recognition' from the host community of the truthfulness of one's union seems to be a priority. In fact, the data clearly suggest that the private sphere of the couple is sensitive to discriminatory social looks.

As Varro (2003) claims, it is necessary 'to recognize the mixite as a social generalised fact' (ivi, p. 229) instead of ignoring the 'Other' with the expectation that the same will disappear in the assimilation process. Therefore, the mutual relation between identity, intimate and macro spheres push towards new intimacy as a citizenship dimension (Oleksy, Hearn \& Golanska, 2011). In fact, despite the increase of borders controls, in all European territory besides the Italian one (Foucher, 1998), the spontaneously relational barriers become more permeable. There are multitudes of lives, cross-borders hopes, dreams and projects of more satisfying life, people who love each other that ask the freedom to love without prejudices 
(Isin, 2009). They are individuals who challenge institutional policies to make progress as ‘intimate citizens' (Roseneil et al., 2012).

For future reflections, we think that would be useful to carry out transnational studies to deepen the weight of discrimination and conjugal satisfaction. It could be also interesting to improve deeply the comprehension of mechanisms, which influence positively the life quality of mixed couples to take into account in preventive action of marital separations and in promoting family wellbeing (Negy, Hammons, Reig-Ferrer, \& Carper 2010).

In this regard, despite the current study represents an important step in this direction, it can be helpful a qualitative follow-up aimed not specifically on the foreign partner as "unique carrier of diversity" but mainly on the dyad.

\section{REFERENCES}

Adsera, A. \& Ferrer, A. (2014). Immigrants and Demography: Marriage, Divorce, and Fertility, IZA Discussion Paper, 7982. Bonn: Institute for the Study of Labor (IZA).

Alba, R., \& Nee, V. (2003). Remaking the American mainstream Assimilation and contemporary immigration. Cambridge, MA: Harvard University Press.

Allport, G. W. (1935). Attitudes. In C. Murchison (Ed.), A Handbook of Social Psychology (pp. 798844). Worcester, MA: Clark University Pres.

Arpino, B., \& de Valk, H. (2018). Comparing Life Satisfaction of Immigrants and Natives Across Europe: The Role of Social Contacts. Social Indicators Research, 37(3): 1163-1184. https://doi.org/10.1007/s11205-017-1629-x

Azzolini, D., \& Guetto, R. (2017). The impact of citizenship on intermarriage. Quasi-experimental evidence from two European Union Eastern enlargements. Demographic Research, 36, 12991336. https://doi.org/10.4054/DemRes.2017.36.43 
Balistreri, K. S., Joyner, K., \& Kao, G. (2017). Trading Youth for Citizenship? The Spousal Age Gap in Cross-Border Marriages. Population and Development Review, 43(3), 443-466. https://doi.org/10.1111/padr.12072

Berry, J. W. (1997). Immigration, acculturation, and adaptation. Applied Psychology, 46(1), 5-68. https://doi.org/10.1111/j.1464-0597.1997.tb01087.x

Berry, J. W. (2001). A psychology of immigration. Journal of Social Issues, 57, 615-631. https://doi.org/10.1111/0022-4537.00231

Berry, J. W. (2003). Conceptual approaches to acculturation. In K. Chun, P. Balls Organista, \& G. Marin (Eds), Acculturation: Advances in theory, measurement and application (pp. 17-37). Washington: APA Books.

Berry, J. W. (2011). Intercultural relations in plural societies: Research derived from Canadian multiculturalism policy. Canadian Ethnic Studies, 43/44(3-1), 5-18.

Berry, J.W. Phinney, J.S., Sam, D.L. \& Vedder, P. (Eds.) (2006). Immigrant youth in cultural transition: acculturation, identity and adaptation across national contexts. Mahwah: Lawrence Erlbaum Associates.

Bertolani, B. (2015). Pujabis in Italy: The Role of Ethnic and Family Networks in Immigration and Social Integration. In S. Irudaya Rajan, V. J. Varghese \& Aswini Kumar Nanda (Eds.), Migrations, Mobility and Multple Affiliations: Punjabis in a Transnational World (pp. 319-337). Cambridge: University Press.

Bratter, J. L., \& Eschbach, K. (2006). 'What about the couple?' Interracial marriage and psychological distress. Social Science Research, 35(4), 1025-1047. https://doi.org/10.1016/j.ssresearch.2005.09.001

Bronfenbrenner, U. (1986). Ecology of the family as a context for human development: Research perspectives. Developmental Psychology, 22, 723-742.

Brown, R. (2000). Social Identity Theory: past achievements, current problems and future challenges. European Journal of Social Psychology, 30, 745-778. 
Brown, R., Condor, S., Mathews, A., Wade, G., \& Williams, J. (1986). Explaining intergroup differentiation in an industrial organization. Journal of Occupational Psychology, 59(4), 273-286. http://dx.doi.org/10.1111/j.2044-8325.1986.tb00230.x

Caballero, C., Edwards, R. \& Smith, D. (2008). Cultures of mixing: understanding partnerships across ethnicity. 21st Century Society, 3(1), 49-63. https://doi.org/10.1080/17450140701749171

Carol, S. (2013). Is Blood Thicker Than Water? The Role of Family and Gender Values for the Social Distance between Muslim Migrants and Natives in Western Europe. Doctoral Dissertation. Berlin: Humboldt-Universität zu Berlin.

Cassepp-Borges, V. \& Teodoro, M. (2007). Propriedades psicométricas da versão brasileira da escala triangular do amor de Sternberg. Psicologia: Reflexão e Crítica, 20(3), 513-522. http://dx.doi.org/10.1590/S0102-79722007000300020

Castro Solano, A. (2011). La evaluación de las competencias culturales de los líderes mediante el Inventario de Adaptación Cultural. Anales de Psicología de la Universidad de Murcia, 27(2), 507517.

Choi, K. H., Tienda, M., Cobb-Clark, D. \& Sinning, M. (2012). Immigration and Status Exchange in Australia and the United States. Research on Social Stratification and Mobility, 30(1): 49-62. http://dx.doi.org/10.1016/j.rssm.2011.08.002.

Diener, E., Emmons, R. A., Larsen, R. J., \& Griffin, S. (1985). The Satisfaction with Life. Scale. Journal of Personality Assessment, 49(1), 71-75. https://doi.org/10.1207/s15327752jpa4901_13

Duckitt, J., \& Parra, C. (2004). Dimensions of Group Identification and Out-Group Attitudes in Four Ethnic Groups in New Zealand. Basic and Applied Social Psychology 26(4), 237-247. http://dx.doi.org/10.1207/s15324834basp2604_1

Eggebø, H. (2013). A Real Marriage? Applying for Marriage Migration to Norway. Journal of Ethnic and Migration Studies, 39(5), 773-789. https://doi.org/10.1080/1369183X.2013.756678

Espinosa, A., Freire, S., \& Ferrándiz, J. (2016). Identificación colectiva y bienestar en una comunidad rural de la costa norte del Perú. Revista de Psicología, 34(1), 201-219. http://dx.doi.org/10.18800/psico.201601.008 
Esses, V. M., Dovidio, J. F., Jackson, L. M., \& Armstrong, T. L. (2001). The immigration dilemma: The role of perceived group competition, ethnic prejudice, and national identity. Journal of Social Issues, 57(3), 389-412. http://dx.doi.org/10.1111/0022-4537.00220

Faist, T., Fauser, M., \& Reisenauer, E. (2013). Transnational Migration. Cambridge: Polity Press.

Foucher, M. (1998). The Geopolitics of European Frontiers. In M. Anderson and E. Bort (Eds.), The Frontiers of Europe. London: Pinter.

Fruggeri, L. (2007). Il caleidoscopio delle famiglie contemporanee. La pluralità come principio di metodo. In P. Bastianoni, \& A. Taurino (Eds.), Famiglie e genitorialità oggi (pp. 41-67). Milano: Unicopli.

Furtado, D. (2012). Human Capital and Interethnic Marriage Decisions. Economic Inquiry, 50(1): 82-93. http://dx.doi.org/10.1111/j.1465-7295.2010.00345.x.

Furtado, D. \& Theodoropoulos, N. (2011). Interethnic Marriage: A Choice between Ethnic and Educational Similarities. Journal of Population Economics, 24, 1257-1279. https://doi.org/10.1007/s00148-010-0319-7.

Gaines, S. O., Clark, E. M., \& Afful, S. E. (2015). Interethnic Marriage in the United States: An Introduction. Journal of Social Issues, 71(4), 647-658. https://doi.org/10.1111/josi.12141

Gao, G. (2001). Intimacy, passion, and commitment in Chinese and US American romantic relationships. International Journal of Intercultural Relations, 25(3), 329-342. http://dx.doi.org/10.1016/S0147-1767(01)00007-4

Gergen, K. J. (2009). An invitation to social construction. Sage Pubblications.

Guetto, R., \& Azzolini, D. (2015). An empirical study of status exchange through migrant/native marriages in Italy. Journal of Ethnic and Migration Studies, 41(13), 1-24.

Gurung, R. A. R., \& Duong, T. (1999). Mixing and Matching: Assessing the Concomitants of MixedEthnic Relationships. Journal of Social and Personal Relationships, 16(5), 639-

657. https://doi.org/10.1177/026540759916500

Haslam, S. A., Jetten, J., Postmes, T. \& Haslam, C. (2009). Social Identity, Health and Well-Being: An Emerging Agenda for Applied Psychology. Applied Psychology, 58(1), 1-23. https://doi.org/10.1111/j.1464-0597.2008.00379.x 
Heller, P. E., \& Wood, B. (2000). The influence of religious and ethnic differences on marital intimacy: intermarriage versus intramarriage. Journal of Marital and Family Therapy, 26(2), 241252. https://doi.org/10.1111/j.1752-0606.2000.tb00293.x

Helms, H. M., Supple, A. J., Su, J., Rodriguez, Y., Cavanaugh, A. M., \& Hengstebeck, N. D. (2014). Economic pressure, cultural adaptation stress, and marital quality among Mexican-origin couples. Journal of Family Psychology, 28(1), 77-87. http://dx.doi.org/10.1037/a0035738

Hindriks, P., Verkuyten, M., \& Coenders, M. (2014). Interminority Attitudes. The Roles of Ethnic and National Identification, Contact, and Multiculturalism. Social Psychology Quarterly, 77(1), 54-74. https://doi.org/10.1177/0190272513511469

Hombrados, M.I., \& Moscato, G. (2009). Interculturalità e senso di comunitá. In G. Lavanco, M.I. Hombrados (Eds.), Lavoro di comunitá e intervento sociale interculturale. Milano: Franco Agneli. ISTAT. (2016). Matrimoni, Separazione e Divorzi, Anno 2015. Roma: Statistiche Report. Retrieved at www.istat.it.

ILFS (Italian Labour Force Survey). Metadata from 2005 to 2012. Retrieved at https://www.istat.it/en/archive/36394

Isin, E. F. (2009). Citizenship in flux: The figure of the activist citizen. Subjectivity, 29(1), 367-388. https://doi.org/10.1057/sub.2009.25

Joseph, T. K., Yun, S. Q., \& Teya, K. (2017). The Influence of Religion on Mixed Marriages among Africans and Chinese in China: A Case Study of Inter Ethnic Marriages in Yiwu. Journal of Sociology and Social Work, 5(1), 122-130. https://doi.org/10.15640/jssw.v5n1a12

Kalmijn, M. (2011). Country differences in the effects of divorce on well-being: The role of norms, support, and selectivity. European Sociological Review, 26, 137-153.

Kenyon, D. B. \& Carter, J. S. (2011). Ethnic identity, sense of community, and psychological well $\square$ being among northern plains American Indian youth. Journal of Community Psychology, 39(1), 19. https://doi.org/10.1002/jcop.20412

Killian, K. (2012). Resisting and complying with homogamy: Interracial couple's narratives about partner differences. Counselling Psychology Quarterly, 25(2), 125-135. https://doi.org/10.1080/09515070.2012.680692 
Lehmiller, J. J. \& Agnew C. R. (2006). Marginalized Relationships: The Impact of Social Disapproval on Romantic Relationship Commitment. Personality and Social Psychology Bulletin, 32(1), 40-51. https://doi.org/10.1177/0146167205278710

Leslie, L. A., \& Young, J. L. (2015). Interracial Couples in Therapy: Common Themes and Issues. Social Issues, 71(4), 788-803. https://doi.org/10.1111/josi.12149

Mancini, T., Panari, C., \& Fruggeri, L. (2013). Intercultural families between definitions and social change. Psicologia di comunità, 1, 11-19. http://dx.doi.org/10.3280/PSC2013-001002

Merton, R. K. (1941). Intermarriage and the Social Structure: Fact and Theory. Psychiatry, 4, 361374.

Molina, B., Burnett, J. A., \& Estrada, D. (2004). Cultural communities: Challenges and opportunities in the creation of happily ever after stories of intercultural couplehood. The Family Journal: Counseling and Therapy for Couples and Families, 1(2), 139-147.

Moscato, G. (2012). Familias interculturales en Espana: análisis de la satisfacción vital. Portularia, $12,35-43$.

Navas, M., Pumares, P., Sánchez, J., García, M. C., Rojas, A. J., \& Cuadrado, I. (2004). Las actitudes de aculturación de autóctonos e inmigrantes en Almería a través del modelo ampliado de aculturación relative. In D. Uclés, \& J. F. Giménez (Eds.), Informe económico de la provincia de Almería, 2003. El reto de la inmigración (pp. 120-140). Almería: Cámara de Comercio, Industria y Navegación de Almería.

Negy, C., Hammons, M. E., Reig-Ferrer, A., \& Carper, T. M. (2010). The importance of addressing acculturative stress in marital therapy with Hispanic immigrant women. International Journal of Clinical and Health Psychology, 10(1), 5-21.

Novara, C., \& Lavanco, G. (2014). Bicultural Couples from Family to Community: Educational Styles and Place Identity. In E. Di Giovanni (Ed.), Facets of Women's Migration (pp. 49-68). Newcastle upon Tyne: Cambridge Scholars Publishing. ISBN 978-1-4438-6138-0.

Novara, C., Serio, C. \& Lavanco G. (2017). Teachers' Representations on Adoptive Families and Educational Practices: New Challenges in Teachers' Preparation. Adoption Quarterly, 20(2), 135154. https://doi.org/10.1080/10926755.2016.1201707 
Oleksy, E. H., Hearn, J., \& Golanska, D. (Eds.) (2011). The Limits of Gendered Citizenship: Contexts and Complexities. New York: Routledge.

Padilla, A., \& Perez, W. (2003). Acculturation, social identity, and social cognition: A new perspective. Hispanic Journal of Behavioral Science, 25, 35-55.

Padilla, M. B., Hirsch, J. S., Munoz-Laboy, M., Sember, R., \& Parker, R. G. (Eds.) (2007). Love and globalization: Transformations of intimacy in the contemporary world. Nashville, TN: Vanderbilt University Press.

Pagliaro, S., Ellemers, N., Barreto, M., \& Leach, C. W. (2010). Strategie (individuali vs. collettive) di gestione dell'identità sociale: Il ruolo delle norme di gruppo e del profitto personale. Psicologia Sociale, 3, 387-401.

Panari, C., Mancini, T., \& Fruggeri, L. (2010). The intercultural families' challenges: A "cultural" question? The cultural psychology perspective. Rivista di Studi Familiari, 2, 42-59.

Parisi, R. (2015) Practices and rhetoric of migrants' social exclusion in Italy: intermarriage, work and citizenship as devices for the production of social inequalities. Identities, 22(6), 739-756. http://dx.doi.org/10.1080/1070289X.2014.950967

Phinney, J. (2003). Ethnic identity and acculturation. In K. Chun, P. Organista, \& G. Marin (Eds.), Acculturation: Advances in theory, measurement, and applied research (pp. 63-81). Washington, DC: American Psychological Association.

Potarca, G., \& Mills, M. (2012). Racial homophily and exclusion in online dating preferences: a cross-national comparison. Paper presented at European Population Conference, Stockholm, Sweden.

Qian, Z., \& Lichter, D. (2007). Changing Patterns of Interracial Marriage in a Multiracial Society. Journal of Marriage and Family 73(5), 1065-1084. http://dx.doi.org/10.1111/j.17413737.2011.00866.x

Riva, E. F. M. (2011). Interreligious and Intercultural Familiesin Italy: An Analysis of North AfricanItalian Marriages. Journal of Muslim Mental Health, 5(3), 301326, DOI: $10.1080 / 15564908.2010 .551277$ 
Rodríguez-García, D. (2015). Intermarriage and integration revisited international experiences and cross-disciplinary approaches. Annals American Academy Political Science and Social Sciences, 662(1), 8-36. http://dx.doi.org/10.1177/0002716215601397

Romano, D. (2008). Intercultural marriages: Promises and pitfalls (Ed.). Boston, MA: Intercultural Press.

Roseneil S., Crowhurst I., Hellesund T., Santos A.C., Stoilova M. (2012). Remaking Intimate Citizenship in Multicultural Europe: Experiences Outside the Conventional Family. In B. Halsaa, S. Roseneil, S. Sümer (Eds), Remaking Citizenship in Multicultural Europe. Citizenship, Gender and Diversity. London: Palgrave Macmillan. https://doi.org/10.1057/9781137272

Schmitt, M. T., \& Branscombe, N. R. (2002). The meaning and consequences of perceived discrimination in advantaged and privileged social groups. European Review of Social Psychology, 12(1), 167-199. http://dx.doi.org/10.1080/14792772143000058

Skowroński, D. P., Danx, F. T., Ho Wen Wan, D. J., Ying Cherie, T. S., Fernandez, T. M.

Waszyńska, K. (2014). Introductory Analysis of Factors Affecting Intercultural Couples in the Context of Singapore. Studia Edukacyjne, 30, 263-268. http://dx.doi.org/10.14746/se.2014.30.15

Song, M. (2009). Is Intermarriage a Good Indicator of Integration? Journal of Ethnic and Migration Studies, 35(2), 331-348. DOI: 10.1080/13691830802586476

Sternberg, R. J. (1997). Construct validation of a triangular love scale. European Journal of Social Psychology, 27(3), 313-335. http://dx.doi.org/10.1002/(SICI)1099-0992(199705)27:3<313::AIDEJSP824>3.0.CO;2-4

Tajfel, H. (1981). Human groups and social categories. Cambridge, UK: Cambridge University Press.

Tajfel, H., \& Turner, J. C. (1979). An integrative theory of intergroup conflict. In W. G. Austine, \& S. Worchel (Eds.), The social psychology of intergroup relations (pp. 33-47). Monterey, CA: Brooks Cole.

Tognetti Bordogna, M. (2005). Ricongiungere la famiglia altrove. Milano: FrancoAngeli.

Tognetti Bordogna, M. (Ed.) (1996). Legami familiari e migrazione: I matrimoni misti. Torino: Harmattan. 
Torqabeh, H. M., Firouz Abadi, A., \& Haqshenas, H. (2006). Relations between love styles and marital satisfaction. The Journal of Mazandaran University of Medical Sciences, 16(54), 99-109.

Troy, A. B., Lewis-Smith, J., \& Laurenceau, J. (2006). Interracial and intraracial romantic relationships: The search for differences in satisfaction, conflict, and attachment style. Journal of Social and Personal Relation-ships, 23(1), 65-80.

Varro, G. (2003). Sociologie de la mixité. De la mixité amoureuse aux mixitès sociales et culturelles. Paris: Berlin.

Vedder, P. H., Van de Vijver, V. F., \& Liebkind, K. (2006). Predicting immigrant youth's adaptation across countries and ethnocultural groups. In J. Berry, J. Phinney, D. Sam, \& P. H. Vedder (Eds.), Immigrant youth in cultural transition: Acculturation, identity and adaptation across national contexts (pp. 143-166). Mahwah, NJ: Lawrence Erlbaum Associates.

Waldman, K., \& Rubalcava, L. (2005). Psychotherapy with intercultural couples: A contemporary psychodynamic approach. American Journal of Psychotherapy, 59(3), 227-246.

Ward, C. (2004). Psychological theories of culture contact and their implications for intercultural training and interventions. In D. Landis, J. Bennet, \& M. Bennett (Eds.), Hand book of intercultural training (pp. 185-216). Thousand Oaks, CA: Sage.

Ward, C., \& Kennedy, A. (2001). Coping with Cross-Cultural Transition. Journal of Cross-Cultural Psychology, 32(5), 636-642. https://doi.org/10.1177/0022022101032005007

Ward, C., \& Rana-Deuba, A. (1999). Acculturation and adaptation revisited. Journal of CrossCultural Psychology, 30(4), 422-442. http://dx.doi.org/ 10.1177/0022022199030004003

Wieling, E. (2003). Latino/a and white marriages: A pilot study investigating the experiences of interethnic couples in the United States. Journal of Couple and Relationship Therapy, 2, 415. https://doi.org/10.1300/J398v02n02_04

Yodanis, C., \& Lauer, S. (2017). Multiculturalism in interethnic intimate relationships. Families, Relationships, and Societies, 6(1), 125-140. https://doi.org/10.1332/204674315X14479283205364 
Table 1 - Demographic Variables

\begin{tabular}{|c|c|c|c|c|}
\hline 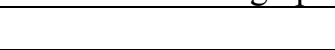 & Couple's Variables & Foreign partner & & Autochthonous partner \\
\hline & & $u(s d)$ & $\%$ & $u(s d) \quad \%$ \\
\hline Married & $73.3 \%$ & & & \\
\hline Living together & $26.7 \%$ & & & \\
\hline Age & & $36.63(10.21)$ & & $38.5(10.9)$ \\
\hline Children (Yes) & $52.9 \%$ & & & \\
\hline Men & & & 41.9 & 58.1 \\
\hline Women & & & 58.1 & 41.9 \\
\hline With employment & & & 77.7 & 81.7 \\
\hline Years since migration & & $12.81(9.6)$ & & \\
\hline Religions & & & & \\
\hline Christian & & & 53.5 & 90.7 \\
\hline Muslim & & & 28.7 & 3.1 \\
\hline Orthodox & & & 11.9 & 1.0 \\
\hline Other & & & 5.9 & 5.1 \\
\hline Geographical Origin & & & & \\
\hline UE (before 2004) & & & 22.3 & \\
\hline UE (after 2004) & & & 14.6 & \\
\hline Africa & & & 26.2 & \\
\hline South-America & & & 14.6 & \\
\hline Other European count & & & 12.6 & \\
\hline +USA+Australia & & & & \\
\hline Magreb \& Middle Eas & & & 9.7 & \\
\hline Migration Type & & & & \\
\hline Forced migration & & & 11.5 & \\
\hline Voluntary migration & & & 88.5 & \\
\hline Migration Motives & & & & \\
\hline $\begin{array}{l}\text { To improve ecc } \\
\text { condition }\end{array}$ & nomic & & 43.4 & \\
\hline $\begin{array}{l}\text { Claiming asylum } \\
\text { or refugee status }\end{array}$ & & & 1.9 & \\
\hline Studies or training & & & 9.6 & \\
\hline $\begin{array}{l}\text { Family reunification a } \\
\text { or affective motives }\end{array}$ & & & & \\
\hline Others & & & 10.1 & \\
\hline
\end{tabular}


Table 2 - Comparison between sub-samples (Anova)

\begin{tabular}{lllllll}
\hline & Partner & $\boldsymbol{N}$ & Means & $\boldsymbol{S . D .}$ & $\boldsymbol{F}$ & $\mathbf{p}$ \\
\hline Ingroup & Italian & 105 & 3.84 & .80 & 2.941 & .05 \\
Identification & Foreign & 104 & 4.00 & .60 & & \\
Outgroup & Italian & 105 & 3.17 & .59 & & NS \\
Identification & Foreign & 104 & 3.30 & .69 & & \\
Couple & Italian & 103 & 2.01 & .49 & & NS \\
Discrimination & Foreign & 104 & 2.09 & 49 & \\
Conjugal & Italian & 104 & 4.44 & .67 & \\
Satisfaction & Foreign & 104 & 4.42 & .69 & & \\
Satisfaction with life & Italian & 105 & 5.21 & 1.26 & & NS \\
& Foreign & 104 & 5.06 & 1.38 & & \\
\hline
\end{tabular}

Table 3 - Comparison within sub-sample (foreign partner) (Anova)

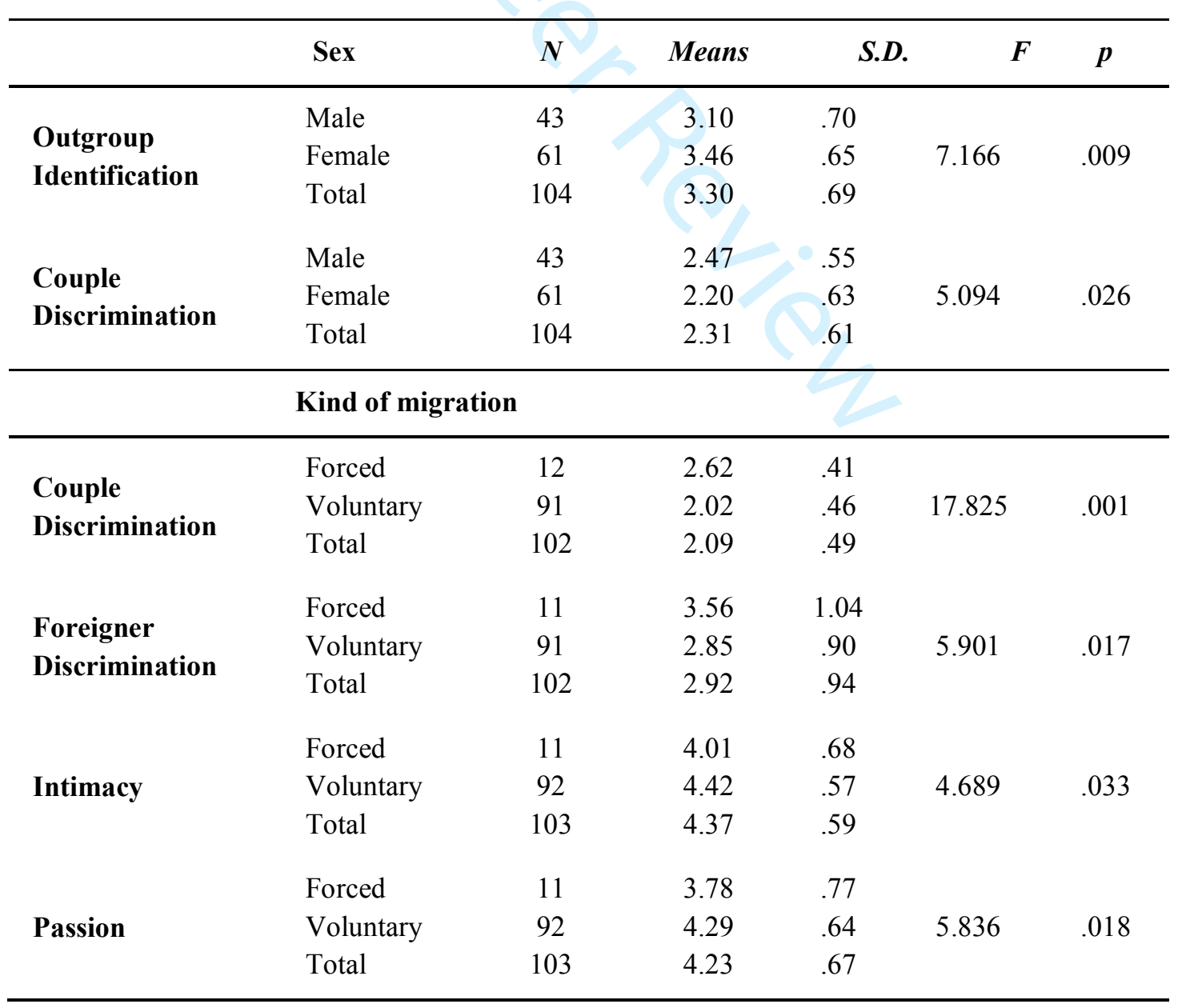




\begin{tabular}{|c|c|c|c|c|c|c|}
\hline & Sense of $\mathbf{R}$ & & & & & \\
\hline \multirow{5}{*}{$\begin{array}{l}\text { Ingroup } \\
\text { Identification }\end{array}$} & None & 17 & 3.79 & .43 & \multirow{5}{*}{5.145} & \multirow{5}{*}{.002} \\
\hline & Low & 21 & 3.80 & .74 & & \\
\hline & Medium & 46 & 4.00 & .55 & & \\
\hline & High & 19 & 4.43 & .48 & & \\
\hline & Total & 103 & 4.01 & .60 & & \\
\hline \multicolumn{7}{|c|}{ Religion } \\
\hline \multirow{5}{*}{$\begin{array}{l}\text { Couple } \\
\text { Discrimination }\end{array}$} & Christian & 54 & 1.96 & .44 & \multirow{5}{*}{3.019} & \multirow{5}{*}{.022} \\
\hline & Muslim & 29 & 2.34 & .52 & & \\
\hline & Orthodox & 12 & 2.02 & .53 & & \\
\hline & Other & 6 & 2.10 & .56 & & \\
\hline & Total & 101 & 2.09 & .50 & & \\
\hline \multirow{5}{*}{$\begin{array}{l}\text { Foreigner } \\
\text { Discrimination }\end{array}$} & Christian & 53 & 2.27 & .85 & \multirow{5}{*}{3.185} & \multirow{5}{*}{.017} \\
\hline & Muslim & 28 & 3.36 & .94 & & \\
\hline & Orthodox & 12 & 2.50 & .88 & & \\
\hline & Other & 6 & 2.80 & 1.16 & & \\
\hline & Total & 99 & 2.73 & .93 & & \\
\hline \multicolumn{7}{|c|}{ Interreligious couple } \\
\hline \multirow{3}{*}{$\begin{array}{l}\text { Couple } \\
\text { Discrimination }\end{array}$} & Yes & 43 & 2.24 & .54 & \multirow{3}{*}{7.049} & \multirow{3}{*}{.009} \\
\hline & No & 56 & 1.98 & .45 & & \\
\hline & Total & 99 & 2.09 & .50 & & \\
\hline \multirow{3}{*}{$\begin{array}{l}\text { Foreigner } \\
\text { Discrimination }\end{array}$} & Yes & 42 & 3.15 & .99 & \multirow{3}{*}{4.859} & \multirow{3}{*}{.030} \\
\hline & No & 55 & 2.74 & .84 & & \\
\hline & Total & 97 & 2.92 & .93 & & \\
\hline \multirow{3}{*}{ Intimacy } & Yes & 42 & 4.24 & .69 & \multirow{3}{*}{4.410} & \multirow{3}{*}{.038} \\
\hline & No & 56 & 4.49 & .48 & & \\
\hline & Total & 98 & 4.38 & .59 & & \\
\hline
\end{tabular}


Table 4 - Comparison within sub-sample (Italian partners) (Anova)

\begin{tabular}{|c|c|c|c|c|c|c|}
\hline & Sex & $N$ & Means & S.D. & $F$ & $p$ \\
\hline Couple & Male & 59 & 1.91 & .50 & 6.127 & .015 \\
\hline \multirow[t]{2}{*}{ Discrimination } & Female & 44 & 2.15 & .44 & & \\
\hline & Total & 103 & 2.01 & .49 & & \\
\hline \multirow[t]{4}{*}{ Passion } & Male & 61 & 4.08 & .66 & 9.788 & .002 \\
\hline & Female & 43 & 4.45 & .50 & & \\
\hline & Total & 104 & 4.23 & .62 & & \\
\hline & Religios & & & & & \\
\hline \multirow[t]{6}{*}{ Ingroup Id } & None & 15 & 3.35 & .97 & 4.106 & .009 \\
\hline & Low & 34 & 4.08 & .72 & & \\
\hline & Medium & 45 & 3.92 & .69 & & \\
\hline & High & 10 & 3.45 & .86 & & \\
\hline & Total & 104 & 3.84 & .80 & & \\
\hline & $\begin{array}{l}\text { Interreli } \\
\text { couple }\end{array}$ & & & & & \\
\hline Couple & Yes & 42 & 2.21 & .51 & 13.575 & .001 \\
\hline \multirow[t]{3}{*}{ Discrimination } & No & 55 & 1.86 & .42 & & \\
\hline & Total & 97 & 2.01 & .49 & & \\
\hline & Job & & & & & \\
\hline \multirow[t]{3}{*}{ Ingroup Id } & No & 19 & 3.42 & .73 & 6.941 & .010 \\
\hline & Yes & 85 & 3.94 & .78 & & \\
\hline & Total & 104 & 3.84 & .80 & & \\
\hline \multirow[t]{3}{*}{ Commitment } & No & 18 & 4.46 & .69 & 4.949 & .028 \\
\hline & Yes & 85 & 4.76 & .47 & & \\
\hline & Total & 103 & 4.71 & .53 & & \\
\hline
\end{tabular}


Table 5 - Correlations among all dimensions for autochthonous and foreigners partners

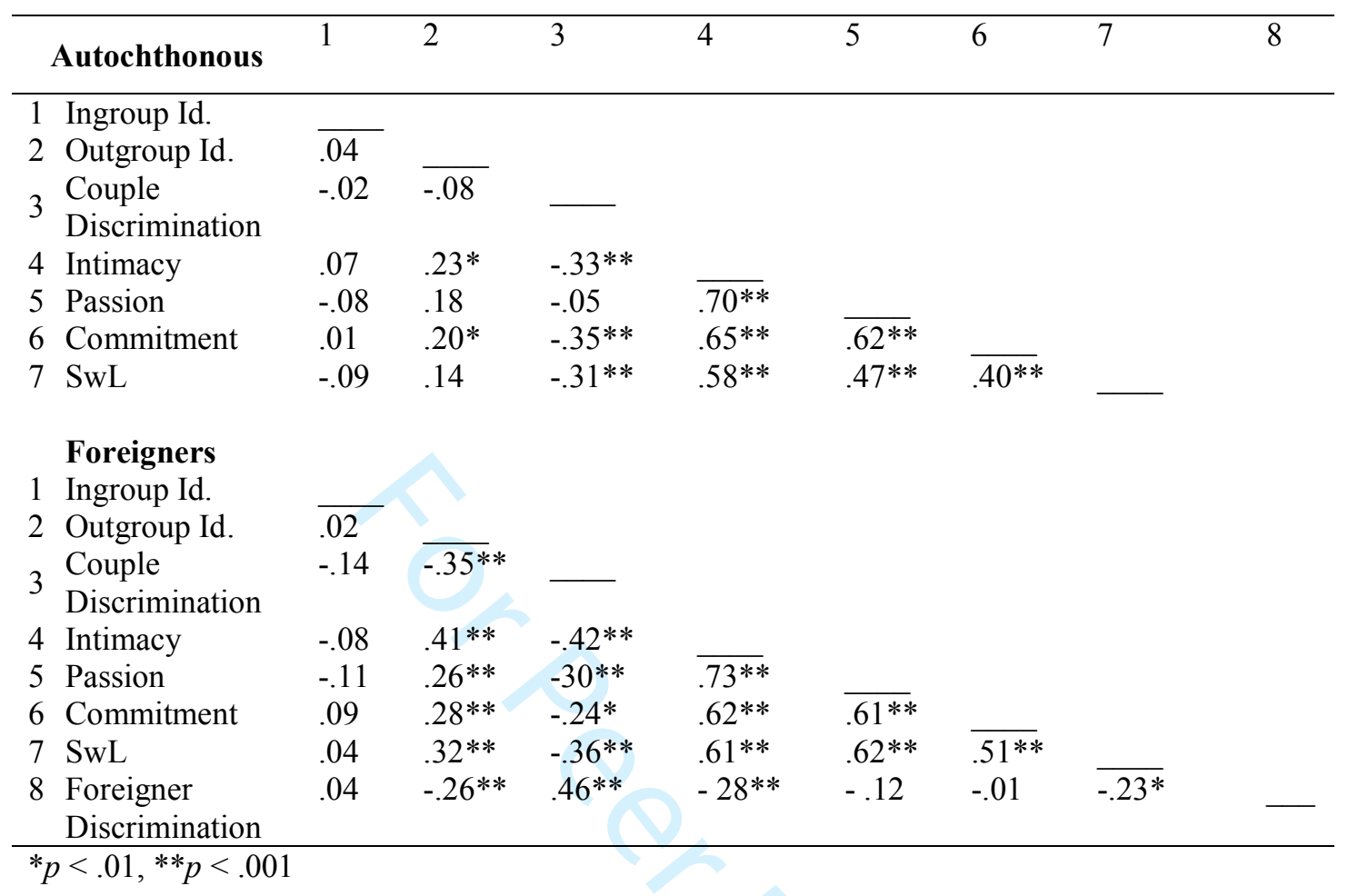

Table 6 - Lineal regression in both sub-groups of native and foreign partners

\begin{tabular}{|c|c|c|c|c|c|c|c|c|}
\hline Model & $\beta$ & $p$ & $\mathbf{t}$ & $R^{2}$ & $\operatorname{Adj} R^{2}$ & $F(d, f)$ & Tolerance & VIF \\
\hline Native partner & & & & .319 & .306 & $\begin{array}{c}23.2 \\
(2,101)\end{array}$ & & \\
\hline Passion & .46 & $.001 * *$ & 5.56 & & & & .89 & 1.12 \\
\hline $\begin{array}{l}\text { Couple } \\
\text { Discrimination }\end{array}$ & -.30 & $.001 * *$ & $\begin{array}{l}- \\
3.67\end{array}$ & & & & .81 & 1.23 \\
\hline Outgroup Id. & .041 & .63 & .48 & & & & .96 & 1.24 \\
\hline Foreign partner & & & & .423 & .411 & $\begin{array}{c}35.8 \\
(2,100)\end{array}$ & & \\
\hline Passion & .56 & $.001 * *$ & 7.05 & & & & .73 & 1.37 \\
\hline $\begin{array}{l}\text { Couple } \\
\text { Discrimination }\end{array}$ & -.19 & $.017^{*}$ & $2 . \overline{42}$ & & & & .74 & 1.35 \\
\hline Outgroup Id. & .13 & .12 & 1.5 & & & & .84 & 1.60 \\
\hline
\end{tabular}

Dependant variables: Satisfaction with Life

Predictor variables: Outgroup identification, Discrimination of couple, Passion.

$* p<.05, * * p<.001$. 
Table 1 - Demographic Variables

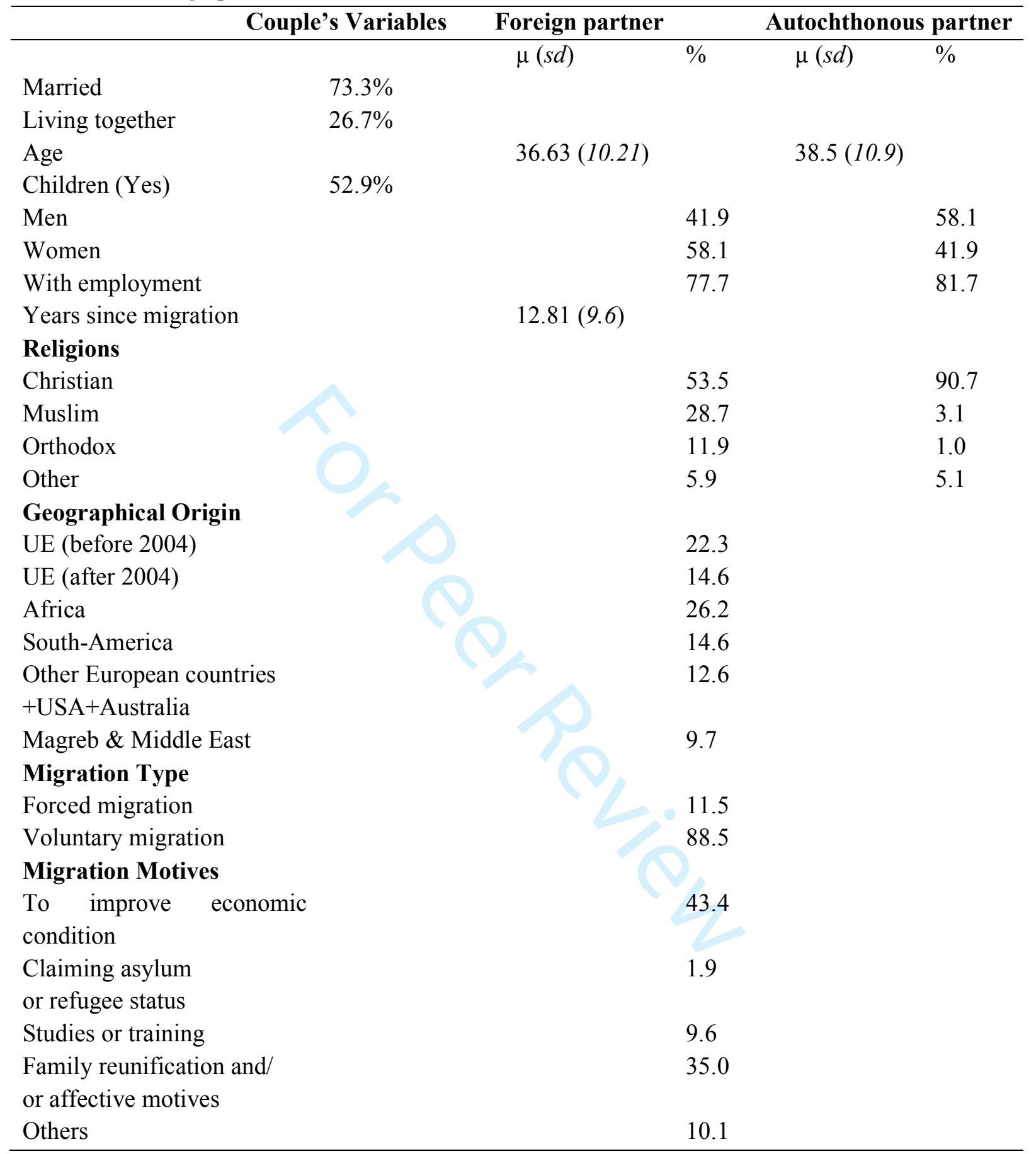


Table 2 - Comparison between sub-samples (Anova)

\begin{tabular}{lllllll}
\hline & Partner & $\boldsymbol{N}$ & Means & $\boldsymbol{S . D .}$ & $\boldsymbol{F}$ & $\mathbf{p}$ \\
\hline Ingroup & Italian & 105 & 3.84 & .80 & 2.941 & .05 \\
Identification & Foreign & 104 & 4.00 & .60 & & \\
Outgroup & Italian & 105 & 3.17 & .59 & & NS \\
Identification & Foreign & 104 & 3.30 & .69 & & \\
Couple & Italian & 103 & 2.01 & .49 & NS \\
Discrimination & Foreign & 104 & 2.09 & 69 & \\
Conjugal & Italian & 104 & 4.44 & .67 & & NS \\
Satisfaction & Foreign & 104 & 4.42 & .69 & & \\
Satisfaction with life & Italian & 105 & 5.21 & 1.26 & & \\
& Foreign & 104 & 5.06 & 1.38 & & \\
\hline
\end{tabular}


Table 3 - Comparison within sub-sample (foreign partner) (Anova)

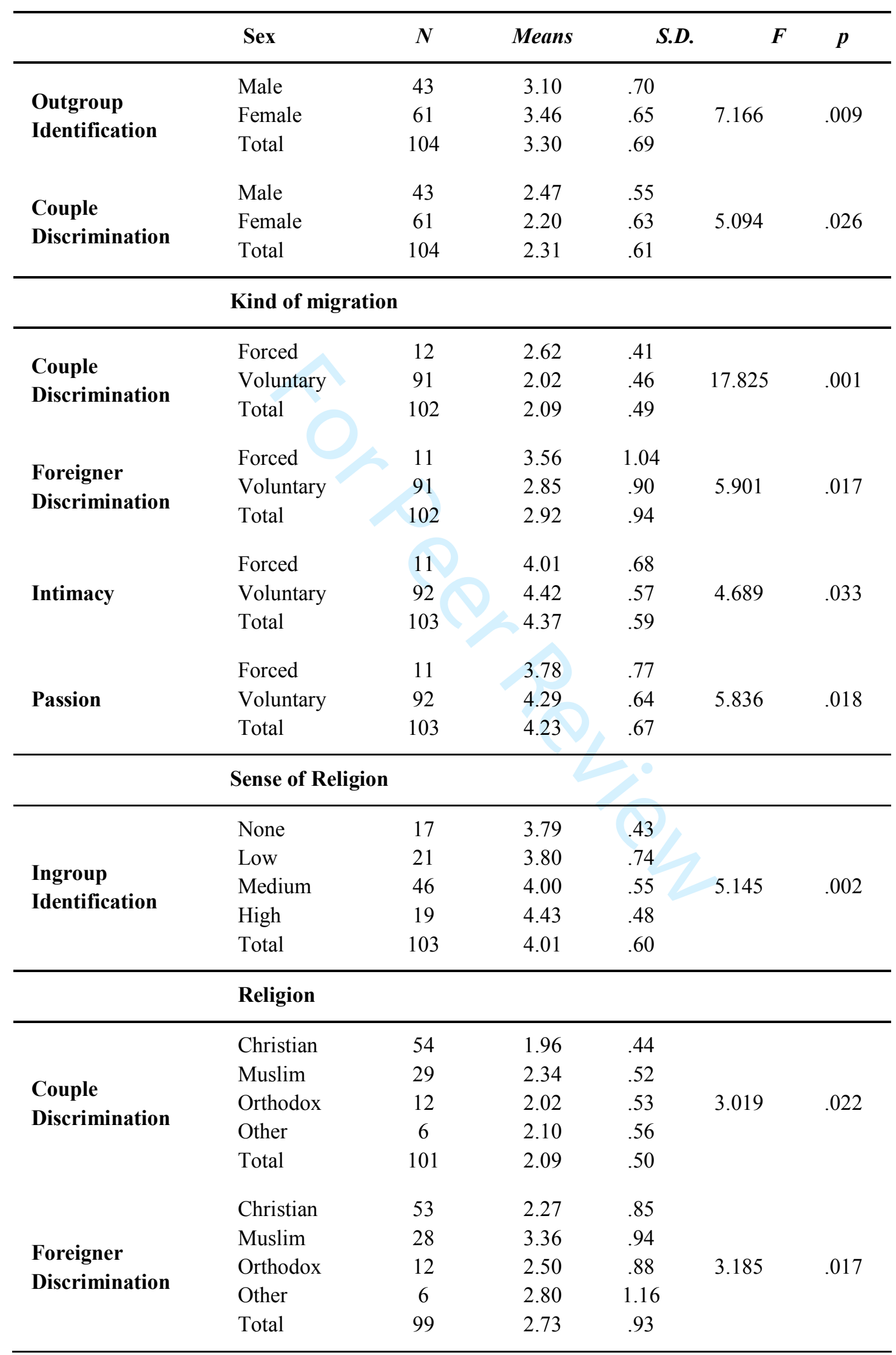




\begin{tabular}{|c|c|c|c|c|c|c|}
\hline & Interr & & & & & \\
\hline \multirow{3}{*}{$\begin{array}{l}\text { Couple } \\
\text { Discrimination }\end{array}$} & Yes & 43 & 2.24 & .54 & \multirow{3}{*}{7.049} & \multirow{3}{*}{.009} \\
\hline & No & 56 & 1.98 & .45 & & \\
\hline & Total & 99 & 2.09 & .50 & & \\
\hline \multirow{3}{*}{$\begin{array}{l}\text { Foreigner } \\
\text { Discrimination }\end{array}$} & Yes & 42 & 3.15 & .99 & \multirow{3}{*}{4.859} & \multirow{3}{*}{.030} \\
\hline & No & 55 & 2.74 & .84 & & \\
\hline & Total & 97 & 2.92 & .93 & & \\
\hline \multirow{3}{*}{ Intimacy } & Yes & 42 & 4.24 & .69 & \multirow{3}{*}{4.410} & \multirow{3}{*}{.038} \\
\hline & No & 56 & 4.49 & .48 & & \\
\hline & Total & 98 & 4.38 & .59 & & \\
\hline
\end{tabular}


Table 4 - Comparison within sub-sample (Italian partners) (Anova)

\begin{tabular}{|c|c|c|c|c|c|c|}
\hline & Sex & $N$ & Means & S.D. & $F$ & $p$ \\
\hline Couple & Male & 59 & 1.91 & .50 & 6.127 & .015 \\
\hline \multirow[t]{2}{*}{ Discrimination } & Female & 44 & 2.15 & .44 & & \\
\hline & Total & 103 & 2.01 & .49 & & \\
\hline \multirow[t]{4}{*}{ Passion } & Male & 61 & 4.08 & .66 & 9.788 & .002 \\
\hline & Female & 43 & 4.45 & .50 & & \\
\hline & Total & 104 & 4.23 & .62 & & \\
\hline & Religiosi & & & & & \\
\hline \multirow[t]{6}{*}{ Ingroup Id } & None & 15 & 3.35 & .97 & 4.106 & .009 \\
\hline & Low & 34 & 4.08 & .72 & & \\
\hline & Medium & 45 & 3.92 & .69 & & \\
\hline & High & 10 & 3.45 & .86 & & \\
\hline & Total & 104 & 3.84 & .80 & & \\
\hline & $\begin{array}{l}\text { Interreli } \\
\text { couple }\end{array}$ & & & & & \\
\hline Couple & Yes & 42 & 2.21 & .51 & 13.575 & .001 \\
\hline \multirow[t]{3}{*}{ Discrimination } & No & 55 & 1.86 & .42 & & \\
\hline & Total & 97 & 2.01 & .49 & & \\
\hline & Job & & & & & \\
\hline \multirow[t]{3}{*}{ Ingroup Id } & No & 19 & 3.42 & .73 & 6.941 & .010 \\
\hline & Yes & 85 & 3.94 & .78 & & \\
\hline & Total & 104 & 3.84 & .80 & & \\
\hline \multirow[t]{3}{*}{ Commitment } & No & 18 & 4.46 & .69 & 4.949 & .028 \\
\hline & Yes & 85 & 4.76 & .47 & & \\
\hline & Total & 103 & 4.71 & .53 & & \\
\hline
\end{tabular}


Table 5 - Correlations among all dimensions for autochthonous and foreigners partners

\begin{tabular}{|c|c|c|c|c|c|c|c|c|}
\hline Autochthonous & 1 & 2 & 3 & 4 & 5 & 6 & 7 & 8 \\
\hline 1 Ingroup Id. & & & & & & & & \\
\hline 2 Outgroup Id. & .04 & & & & & & & \\
\hline Couple & -.02 & -.08 & 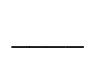 & & & & & \\
\hline Discrimination & & & & & & & & \\
\hline 4 Intimacy & .07 & $.23^{*}$ & $-.33 * *$ & & & & & \\
\hline 5 Passion & -.08 & .18 & -.05 & $\overline{70 * *}$ & & & & \\
\hline 6 Commitment & .01 & $.20 *$ & $-.35 * *$ & $.65 * *$ & $.62^{* *}$ & - & & \\
\hline $7 \mathrm{SwL}$ & -.09 & .14 & $-.31 * *$ & $.58 * *$ & $.47^{* *}$ & $.40^{* *}$ & 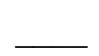 & \\
\hline Foreigners & & & & & & & & \\
\hline 1 Ingroup Id. & & & & & & & & \\
\hline 2 Outgroup Id. & .02 & & & & & & & \\
\hline Couple & -.14 & $-.35 * *$ & & & & & & \\
\hline 3 Discrimination & & & 5 & & & & & \\
\hline 4 Intimacy & -.08 & $.41^{* *}$ & $-.42 * *$ & $\ldots$ & & & & \\
\hline 5 Passion & -.11 & $.26^{* *}$ & $-30 * *$ & $.73 * *$ & 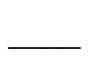 & & & \\
\hline 6 Commitment & .09 & $.28^{* *}$ & $-.24^{*}$ & $.62 * *$ & $.61^{* *}$ & & & \\
\hline $7 \mathrm{SwL}$ & .04 & $.32 * *$ & $-.36 * *$ & $.61^{* *}$ & $.62 * *$ & $.51^{* *}$ & & \\
\hline 8 Foreigner & .04 & $-.26 * *$ & $.46^{* *}$ & $-28 * *$ & -.12 & -.01 & $-.23 *$ & 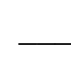 \\
\hline Discrimination & & & & & & & & \\
\hline
\end{tabular}


Table 6 - Lineal regression in both sub-groups of native and foreign partners

\begin{tabular}{|c|c|c|c|c|c|c|c|c|}
\hline Model & $\bar{\beta}$ & $p$ & $\mathbf{t}$ & $R^{2}$ & $\operatorname{Adj} R^{2}$ & $F(d, f)$ & Tolerance & VIF \\
\hline Native partner & & & & .319 & .306 & $\begin{array}{c}23.2 \\
(2,101)\end{array}$ & & \\
\hline Passion & .46 & $.001 * *$ & 5.56 & & & & .89 & 1.12 \\
\hline $\begin{array}{l}\text { Couple } \\
\text { Discrimination }\end{array}$ & -.30 & $.001 * *$ & $\begin{array}{c}- \\
3.67\end{array}$ & & & & .81 & 1.23 \\
\hline Outgroup Id. & .041 & .63 & .48 & & & & .96 & 1.24 \\
\hline Foreign partner & & & & .423 & .411 & $\begin{array}{c}35.8 \\
(2,100)\end{array}$ & & \\
\hline Passion & .56 & $.001 * *$ & 7.05 & & & & .73 & 1.37 \\
\hline $\begin{array}{l}\text { Couple } \\
\text { Discrimination }\end{array}$ & -.19 & $.017 *$ & $\begin{array}{c}- \\
2.42\end{array}$ & & & & .74 & 1.35 \\
\hline Outgroup Id. & .13 & .12 & 1.5 & & & & .84 & 1.60 \\
\hline
\end{tabular}

Dependant variables: Satisfaction with Life

Predictor variables: Outgroup identification, Discrimination of couple, Passion.

$* p<.05, * * p<.001$. 